Zeszyty Naukowe Szkoły Głównej Gospodarstwa Wiejskiego w Warszawie

Problemy Rolnictwa Światowego tom 18 (XXXIII), zeszyt 4, 2018: 345-358

DOI: 10.22630/PRS.2018.18.4.124

Grzegorz Maciejewski $^{1}$

Uniwersytet Ekonomiczny w Katowicach

\title{
Ekonomiczna dostępność żywności w państwach Unii Europejskiej
}

\section{Economic Access to Food in Countries of the European Union}

\begin{abstract}
Synopsis. Zaspokojenie głodu i pragnienia jest podstawowym prawem przysługującym każdemu człowiekowi. Ekonomiczna dostępność żywności stanowi jeden z czterech koniecznych warunków do zapewnienia bezpieczeństwa żywnościowego państw i ich obywateli. Dane FAO, Parlamentu Europejskiego czy statystyki Eurostatu pokazują, że problem ekonomicznej dostępności żywności dotyczy również państw UE. Celem prezentowanego artykułu jest ukazanie wielkości problemu ekonomicznej dostępności żywności w państwach Wspólnoty. Przeprowadzone badania dowodzą, że opisywany problem nie może być lekceważony. Wydatki na żywność stanowią wciąż jedną z głównych grup wydatków gospodarstw domowych, w państwach takich jak Rumunia czy Litwa przekraczając $20 \%$ ogółu ponoszonych wydatków. Ponad połowa obywateli UE boryka się z trudnościami związanymi z pokryciem wydatków osiąganymi dochodami. Sytuację utrudnia także nierównomierny rozkład niedożywienia występujący w poszczególnych państwach.
\end{abstract}

Słowa kluczowe: ekonomiczna dostępność żywności, bezpieczeństwo żywnościowe, konsumpcja żywności, dochody gospodarstw domowych, Unia Europejska

\begin{abstract}
Satisfying hunger and thirst is a basic right of every human. The economic access to food is one of the four necessary conditions to provide food security of countries and their citizens. Data from FAO, European Parliament or statistics from Eurostat show that the problem of economic access to food concerns countries of the European Union as well. The aim of the paper is to present the magnitude of the problem of economic access to food in the EU countries. The conducted research proves that the described problem cannot be underestimated. The food expenditure still constitutes to be one of the main groups of households' expenditures, for instance in countries like Romania or Lithuania, where it exceeds $20 \%$ of overall expenditure. More than half of the citizens of the EU struggle to cover the expenditure with earned income. The situation is even harder because of the uneven distribution of malnutrition in particular countries.
\end{abstract}

Key words: economic access to food, food security, food consumption, household income, European Union

JEL Classification: D14, D18, O15, O57, Q18

\section{Wprowadzenie}

Obserwowany obecnie, niespotykanie szybki rozwój kulturowy, społeczny i gospodarczy współczesnych społeczeństw, daje nadzieję na poprawę jakości życia wszystkich mieszkańców Ziemi, zwłaszcza tych mających trudności z zaspokojeniem swoich podstawowych potrzeb. W sierpniu 2015 roku 193 państwa członkowskie Organizacji Narodów Zjednoczonych (ONZ), osiagnęły kompromis w sprawie dokumentu

${ }^{1}$ dr hab., prof. UE, Katedra Rynku i Konsumpcji, Wydział Ekonomii, UE w Katowicach, ul. 1-go maja 50, 40-286 Katowice, e-mail: grzegorz.maciejewski@ue.katowice.pl; https://orcid.org/0000-0002-1318-0747 
końcowego - nowej agendy "Przekształcanie naszego świata: Agenda na Rzecz Zrównoważonego Rozwoju - 2030” (ONZ, 2018). Idea zrównoważonego rozwoju Ziemi to działania mające na celu ,zaspokojenie podstawowych potrzeb wszystkich ludzi przy jednoczesnym zachowaniu, ochronie i przywracaniu zdrowia i integralności ekosystemu Ziemi, bez zagrożenia możliwości zaspokojenia potrzeb przyszłych pokoleń i bez przekraczania długoterminowych granic pojemności ekosystemu Ziemi” (Kramer, 2011, s. 7). Przyjęty przez Narody Zjednoczone dokument zakłada w latach 2016-2030 realizację 16 celów i 169 zadań. Jednym z Celów Zrównoważonego Rozwoju (Sustainable Development Goals - SDGs) jest wyeliminowanie ubóstwa i głodu we wszystkich ich formach i wymiarach na obszarze całego Świata (ONZ, 2018). Cel ten koresponduje z jednym $\mathrm{z}$ kardynalnych praw przysługujących człowiekowi, jakim jest prawo do zaspokojenia swoich podstawowych potrzeb. Do grupy potrzeb podstawowych, zgodnie z teorią potrzeb A.H. Maslowa (2018), zaliczyć należy w pierwszej kolejności potrzebę zaspokojenia głodu i pragnienia (tzw. potrzeby żywnościowe). Zaspokojenie tych potrzeb warunkuje rozwój dalszych potrzeb człowieka. Spośród ogółu odczuwalnych potrzeb ludzkich potrzeby żywnościowe cechuje najwyższa pilność ich zaspokajania (Dąbrowska i Ozimek, 2014). Determinuje ją biologiczna funkcja żywności, odpowiadająca za utrzymanie człowieka w codziennej sprawności i fizjologii rozwoju fizycznego oraz psychicznego (Gawęcki, 2004). Problemem pierwszoplanowym staje się zatem kwestia zapewnienia bezpieczeństwa żywnościowego wszystkim mieszkańcom Ziemi. Brak zapewnionego bezpieczeństwa żywnościowego prowadzi do niedożywienia, co w dłuższym okresie może prowadzić do wystąpienia chronicznego niedożywienia, prowadzącego w konsekwencji do wielu groźnych chorób mogących zakończyć się w rezultacie zgonem jednostki (Michalczyk, 2012; WHO, 2016).

Problem głodu i niedożywienia nie jest problemem dotykającym wyłącznie krajów rozwijających się. Nie dotyczy także tylko samego niedoboru odpowiedniej ilości i jakości pożywienia, ale również nierównomiernej, niewłaściwej jego dystrybucji. Z jednej strony „w Europie 79 mln obywateli Unii Europejskiej (UE) żyje poniżej progu ubóstwa, a 16 mln jest zależnych od pomocy żywnościowej pochodzącej od instytucji charytatywnych" (dane Parlamentu Europejskiego za A. Obiedzińska, 2016, s. 126). Z drugiej - obserwować można ogromne marnotrawienie żywności wynikające $\mathrm{z}$ takich zjawisk, jak hiperkonsumpcja (kupowanie tylko dla własnej przyjemności i podkreślania swojego statusu), konsumpcjonizm (nadkonsumpcja, nadmierna, niepotrzebna konsumpcja) czy nierównomierne rozlokowanie placówek sieci handlu detalicznego nastawionych głównie na zaspokajanie potrzeb masowego konsumenta, żyjącego w dużych skupiskach miejskich. Kwestia bezpieczeństwa żywnościowego jest zatem wieloobszarowym problemem obejmującym złożone zagadnienia ekonomiczne, polityczne, społeczno-kulturowe, demograficzne i techniczne (European Commission, 2009). Aby zagwarantować jednostce bezpieczeństwo żywnościowe musi zostać spełnionych kilka warunków. Warunkiem kluczowym jest zapewnienie dostępności żywności na poziomie ekonomicznym. Dlatego też celem artykułu jest przedstawienie wielkości problemu ekonomicznego dostępu do żywności obywateli państw Unii Europejskiej.

Artykuł ma charakter poznawczy. Badania na potrzeby niniejszego opracowania przeprowadzone zostały metodą desk research na podstawie krytycznej analizy literatury przedmiotu oraz dostępnych źródeł wtórnych, głównie danych Międzynarodowej Organizacji ds. Wyżywienia i Rolnictwa (Food and Agriculture Organization of the United Nations, FAO) oraz Eurostat. W pierwszej części pracy przedstawiono kwestię 
ekonomicznej dostępności żywności jako kluczowego warunku bezpieczeństwa żywnościowego. W dalszych częściach analizie poddano wielkość siły nabywczej jaką dysponują obywatele państw Unii Europejskiej, poziom jej wystarczalności oraz poziom i miejsce wydatków na żywność w strukturze wydatków ogółem. Wnioski płynące z zaprezentowanego materiału nie wyczerpują $\mathrm{w}$ pełni podjętego tematu, mogą jednak stanowić głos w dyskusji nad efektywniejszym kształtowaniem polityki bezpieczeństwa żywnościowego państw Unii Europejskiej oraz rolą jaką pełni w niej ekonomiczna dostępność żywności.

\section{Ekonomiczna dostępność żywności jako warunek bezpieczeństwa żywnościowego jednostki}

Według najnowszego raportu FAO, po dłuższym okresie spadku, zaobserwowano ponowny wzrost głodu na świecie. Szacuje się, że w 2017 roku na Ziemi żyło blisko 821 mln niedożywionych osób. Innymi słowy 1 osoba na 9 cierpiała niedożywienie (FAO, IFAD, UNICEF, WFP and WHO 2018, s.2). Zdecydowana większość tych ludzi zamieszkuje tereny krajów rozwijających się, głównie z Azji, Afryki oraz Ameryki Łacińskiej i Karaibów. Liczba niedożywionych osób w Europie i Ameryce Północnej nie przekracza 2,5\% ogółu ludności tych regionów, wynosząc około 27,6 mln osób (tab.1).

Tabela 1. Liczba niedożywionych osób na świecie w latach 2005-2017

Table 1. Number of undernourished people in the world in 2005-2017

\begin{tabular}{|c|c|c|c|c|c|c|}
\hline \multirow{2}{*}{ Wyszczególnienie } & \multicolumn{6}{|c|}{ Liczba osób niedożywionych (w mln) } \\
\hline & 2005 & 2010 & 2012 & 2014 & 2016 & $2017^{\mathrm{a}}$ \\
\hline Świat & 945,0 & 820,5 & 805,7 & 783,7 & 804,2 & 820,8 \\
\hline Afryka & 196,0 & 200,2 & 205,2 & 212,5 & 241,3 & 256,5 \\
\hline Afryka Północna & 9,7 & 8,5 & 17,6 & 17,8 & 19,5 & 20,0 \\
\hline Sahara & 176,7 & 181,0 & 187,6 & 194,7 & 221,9 & 236,5 \\
\hline Afryka Wschodnia & 113,5 & 119,1 & 113,3 & 117,1 & 129,6 & 132,2 \\
\hline Afryka Środkowa & 36,2 & 36,5 & 36,4 & 36,1 & 40,8 & 42,7 \\
\hline Afryka Południowa & 3,6 & 4,2 & 4,2 & 4,6 & 5,2 & 5,4 \\
\hline Afryka Zachodnia & 33,0 & 31,9 & 33,7 & 36,9 & 46,3 & 56,1 \\
\hline Azja & 684,4 & 569,9 & 552,2 & 523,1 & 514,5 & 515,1 \\
\hline Azja Centralna & 6,5 & 4,6 & 4,0 & 4,0 & 4,2 & 4,4 \\
\hline Azja Wschodnia & 219,1 & 178,4 & 160,4 & 142,6 & 139,5 & 139,6 \\
\hline Azja Południowo-Wschodnia & 101,7 & 73,7 & 65,1 & 60,6 & 63,6 & 63,7 \\
\hline Azja Południowa & 339,8 & 293,1 & 299,6 & 289,4 & 278,1 & 277,2 \\
\hline Azja Zachodnia & 19,4 & 20,1 & 23,1 & 26,5 & 29,1 & 30,2 \\
\hline Ameryka Łacińska i Karaiby & 51,1 & 40,7 & 38,9 & 38,5 & 38,9 & 39,3 \\
\hline Karaiby & 9,1 & 8,0 & 7,9 & 7,7 & 7,2 & 7,0 \\
\hline Ameryka Łacińska & 42,1 & 32,6 & 31,0 & 30,8 & 31,7 & 32,3 \\
\hline Ameryka Centralna & 12,4 & 11,6 & 11,9 & 11,6 & 11,0 & 11,0 \\
\hline Ameryka Południowa & 29,6 & 21,1 & 19,1 & 19,3 & 20,7 & 21,4 \\
\hline Oceania & 1,8 & 1,9 & 2,0 & 2,3 & 2,6 & 2,8 \\
\hline Europa i Ameryka Północna & $<26,4$ & $<27,0$ & $<27,2$ & $<27,3$ & $<27,5$ & $<27,6$ \\
\hline
\end{tabular}

a - dane szacunkowe

Źródło: FAO, IFAD, UNICEF, WFP and WHO (2018), s. 6. 
Żywność zatem dla bardzo wielu mieszkańców globu wciąż pozostaje dobrem deficytowym, a dążenie do zapewnienia sobie i swoim najbliższym bezpieczeństwa żywnościowego celem priorytetowym ich działań. Wobec problemu głodu i niedożywienia nie pozostawała obojętna społeczność międzynarodowa. Nad zapewnieniem bezpieczeństwa żywnościowego wszystkim mieszkańcom Ziemi na arenie międzynarodowej dyskutowano bowiem już od lat 30. XX wieku (Shaw, 2007). Dopiero jednak w 1974 roku pojęcie to zostało oficjalnie zinterpretowane. Zdaniem J. Małysza stało się to $\mathrm{w}$ wyniku nasilającego się globalnego problemu żywnościowego, gdy w następstwie ogólnoświatowego nieurodzaju skutkującego słabymi zbiorami nastąił gwałtowny spadek zapasów zbóż, obniżenie się podaży i wzrost cen artykułów żywnościowych oraz wyraźny spadek dostępności żywności (Małysz, 2008). Stąd też pierwotnie kwestię bezpieczeństwa żywnościowego odnoszono jedynie do strony podażowej rynku żywności i to tylko w wymiarze międzynarodowym, definiując je jako „dostępność w każdym czasie, w skali całego świata, podaży podstawowych artykułów żywnościowych, dla zachowania ciagłego wzrostu konsumpcji żywności i zrównoważenia fluktuacji produkcji i cen" (Kowalczyk, 2009, s. 15; Krzysztofiak i Pawlak, 2017, s. 181). W przytoczonej definicji zwracano więc uwagę przede wszystkim na fizyczną dostępność żywności. Przez kolejne lata koncepcja bezpieczeństwa żywnościowego ewoluowała, rozszerzając się o kolejne aspekty, takie jak ekonomiczny dostęp do żywności, bezpieczeństwo żywności, dostęp do wystarczającej ilości żywności posiadającej odpowiednie walory odżywcze, dostęp do żywności wychodzącej naprzeciw indywidualnym preferencjom żywieniowym jednostki. Żywność zaczęto także traktować jako podstawę aktywnego i zdrowego życia człowieka (Michalczyk, 2012). Obecnie pojęcie bezpieczeństwa żywnościowego interpretuje się zgodnie z wytycznymi Światowego Szczytu Bezpieczeństwa Żywnościowego, który odbył się w listopadzie 2009 roku w Rzymie. Bezpieczeństwo żywnościowe, jest to zatem ,sytuacja, która istnieje, kiedy wszyscy ludzie mają cały czas fizyczny, ekonomiczny i społeczny dostęp do wystarczającej, bezpiecznej i pożywnej żywności, spełniającej ich potrzeby dietetyczne i preferencje żywieniowe dla prowadzenia aktywnego i zdrowego życia" (FAO, IFAD, UNICEF, WFP and WHO 2018, s.159). Widać zatem, że przedstawiona definicja rozszerza dotychczasowe pojęcie bezpieczeństwa żywnościowego o aspekt społeczny.

Tabela 2. Warunki bezpieczeństwa żywnościowego

Table 2. Food security conditions

\begin{tabular}{l|l}
\hline \multicolumn{1}{c|}{ Warunek } & \multicolumn{1}{c}{ Charakterystyka } \\
\hline Fizyczna dostępność żywności & $\begin{array}{l}\text { Zagwarantowanie społeczeństwu / jednostce odpowiedniej ilości } \\
\text { żywności, która pokryje niezbędną dawkę energetyczną oraz potrzebne } \\
\text { składniki odżywcze. O żywności dostępnej fizycznie mówi się, gdy } \\
\text { znajduje się ona na rynku, można ją wyprodukować w gospodarstwie, } \\
\text { importować bądź otrzymać w ramach pomocy społecznej. }\end{array}$ \\
Ekonomiczna dostępność żywności & $\begin{array}{l}\text { Zagwarantowanie społeczeństwu / jednostce odpowiedniej siły nabywczej } \\
\text { umożliwiającej pozyskanie odpowiedniej ilości fizycznie dostępnej } \\
\text { żywności. } \\
\text { Społeczna dostępność żywności }\end{array}$ \\
$\begin{array}{l}\text { Zagwarantowanie społeczeństwu / jednostce żywności zgodnej } \\
\text { zkulturowymi i społecznymi upodobaniami określonej grupy. } \\
\text { Zagwarantowanie społeczeństwu / jednostce żywności wolnej od } \\
\text { zanieczyszczeń i optymalnej pod względem składników odżywczych. }\end{array}$ \\
\hline
\end{tabular}

Źródło: Opracowanie własne na podstawie: Małysz (2008, s. 88); CFS (2012, s. 4-11); Marzęda-Młynarska (2014, s. 103); Krzysztofiak i Pawlak (2017, s. 182); Obiedzińska (2017, s. 128). 
W oparciu o zaprezentowaną definicję, można wskazać cztery warunki, które muszą być spełnione jednocześnie, aby zostało zapewnione bezpieczeństwo żywnościowe. Przedstawione zostały one w tabeli 2.

Z zaprezentowanego zestawienia jasno zatem wynika, że zagwarantowanie ekonomicznej dostępności żywności jest równie ważnym kryterium osiagnięcia bezpieczeństwa żywnościowego, jak pozostałe trzy warunki. Zagwarantowanie jednostce fizycznego dostępu do żywności bezpiecznej, zgodnej z kulturowymi i społecznymi jej preferencjami nie zda się bowiem na nic, wobec braku siły nabywczej tej jednostki, pozwalającej na zakup oferowanej żywności. Tak więc, aby żywność była w pełni dostępna, jednostka - konsument musi dysponować odpowiednią siłą nabywczą, wysoką na tyle, aby umożliwić mu zakup tej żywności. Na rynku żywności siłę nabywczą konsumenta wyznaczają osiagane przez niego dochody, a także ceny żywności oraz ceny pozostałych towarów i usług dostępnych na rynku (Małysz, 2008). Chcąc zbadać ekonomiczną dostępność żywności, należy odnieść się przede wszystkim do najczesściej wykorzystywanych mierników i wskaźników wielkości tego problemu, a mianowicie: wielkości dochodu rozporządzalnego, poziomu cen żywności, wielkości wydatków na żywność czy udziału wydatków na żywność w wydatkach ogółem (Kapusta, 2016).

\section{Dane i metody}

Materiałem źródłowym, wykorzystanym w części badawczej pracy, są agregaty danych Eurostatu zgromadzone w ramach:

- European Union Statistics on Income and Living Conditions (EU-SILC);

- Classification of Individual Consumption by Purpose (COICOP);

- European System of National and Regional Accounts in the European Union (ESA 2010).

Badanie EU-SILC jest obecnie jedynym tak kompleksowym i wiarygodnym źródłem informacji na temat dochodów ludności, warunków ich życia oraz wybranych obszarów zachowań dotyczących zdrowia, które swym zasięgiem obejmują wszystkie 28 państwa członkowskie UE, a ponadto także Islandię, Norwegię oraz Szwajcarię. Badania te zostały zaprojektowane jako podstawowe źródło wsparcia dla badań ad hoc, ale także jako formalny mechanizm monitorowania postępów w realizacji strategii integracji społecznej "Europa 2020", której celem jest wyprowadzenie co najmniej 20 milionów ludzi z ubóstwa i wykluczenia społecznego oraz zwiększenie zatrudnienia wśród osób w wieku 20-64 do 75\% (Copeland i Daly, 2012; Arora i in., 2015).

$\mathrm{Z}$ kolei COICOP jest jedną $\mathrm{z}$ rodziny klasyfikacji spożycia według celu, opracowanych i rekomendowanych przez ONZ. COICOP stosowana jest również w innych ważnych obszarach statystyki. np. rachunkach narodowych, badaniu budżetów gospodarstw domowych (HBS) i badaniu parytetu siły nabywczej (PPP). Klasyfikacja ta, zarówno w badaniu HBS, PPP jak i HICP jest zgodna $z$ obowiązująca wersją COICOP opublikowaną przez ONZ (GUS, 2013).

ESA 2010 jest systemem zbudowanym w oparciu o uzgodnione międzynarodowe pojęcia, definicje, klasyfikacje i zasady rachunkowości. Tworzy go zbiór wzajemnie ze sobą powiązanych rachunków sporządzonych $\mathrm{w}$ określonym porządku. Każdy z nich odzwierciedla inny rodzaj działalności gospodarczej, prowadzonej przez przedmioty 
klasyfikowane do różnych sektorów instytucjonalnych i prowadzące działalność w kolejnych okresach czasowych (GUS, 2017).

Zgromadzone dane pozwoliły na analizę wysokości przeciętnych dochodów gospodarstw domowych państw UE, wysokości wydatków na żywność, udziału tych wydatków w wydatkach ogółem oraz opinii gospodarstw domowych na temat pokrycia ich miesięcznych wydatków osiagganymi dochodami. Z uwagi na brak kompletnych danych za rok 2017 w momencie przekazania artykułu do wydawnictwa, w niektórych analizach posłużono się danymi z lat 2015 i 2016. Do analizy danych posłużono się metodami wnioskowania logicznego oraz metodą porównawczą. Do prezentacji uzyskanych wyników badań zastosowano formę opisową i tabelaryczną.

\section{Wyniki badań}

W 2017 roku państwa Unii Europejskiej wyeksportowały do swoich dziesięciu głównych partnerów handlowych żywność, napoje i tytoń o wartości blisko 122 mld Euro. Jednocześnie importując tego typu towary o łącznej wartości $112 \mathrm{mld}$. W porównaniu do 2015 roku wartość eksportu żywności, napojów i tytoniu wzrosła o 8,5 mld Euro. W tym samym czasie wartość importu analizowanych dóbr wzrosła o 3,6 mld Euro. Z danych przedstawionych w tabeli 3 widać zatem, że UE jest nie tylko jednym z największych eksporterów żywności na świecie, ale także jednym z jej największych importerów. Kraje wspólnoty stoją zatem z jednej strony przed problemem nadprodukcji żywności, a z drugiej takiego jej rozmieszczenia, aby była dostępna dla wszystkich obywateli wspólnoty.

Tabela 3. Wartość eksportu i importu żywności, napojów i tytoniu państw Unii Europejskiej oraz ich głównych partnerów handlowych w latach 2015-2017 (w mld Euro)

Table 3. Value of export and import of food, drinks and tobacco in the European Union countries and their main trade partners in 2015-2017 (in EUR billion)

\begin{tabular}{|c|c|c|c|c|c|c|c|c|c|}
\hline \multirow{2}{*}{ Wyszczególnienie } & \multicolumn{3}{|c|}{ Eksport } & \multicolumn{3}{|c|}{ Import } & \multicolumn{3}{|c|}{ Bilans } \\
\hline & 2015 & 2016 & 2017 & 2015 & 2016 & 2017 & 2015 & 2016 & 2017 \\
\hline UE28 & 113,2 & 116,0 & 121,7 & 108,4 & 109,1 & 112,0 & 4,8 & 6,8 & 9,7 \\
\hline Brazylia & 43,5 & 42,7 & 44,5 & 7,1 & 8,3 & 7,7 & 36,4 & 34,5 & 36,8 \\
\hline $\begin{array}{l}\text { Chiny (bez Hong } \\
\text { Kongu) }\end{array}$ & 55,4 & 58,4 & 59,4 & 50,7 & 49,9 & 54,4 & 4,7 & 8,5 & 5,0 \\
\hline Indie & 24,7 & 24,2 & 28,0 & 8,7 & 9,7 & 11,0 & 16,1 & 14,5 & 16,9 \\
\hline Japonia & 4,4 & 5,0 & 5,1 & 52,1 & 52,8 & 55,5 & $-47,7$ & $-47,7$ & $-50,4$ \\
\hline Kanada & 34,2 & 33,1 & 34,0 & 29,6 & 29,5 & 30,0 & 4,6 & 3,5 & 4,0 \\
\hline Korea Południowa & 5,7 & 6,2 & 6,5 & 21,5 & 21,6 & 22,9 & $-15,7$ & $-15,4$ & $-16,4$ \\
\hline Meksyk & 23,4 & 25,5 & 28,1 & 17,7 & 17,8 & 18,3 & 5,7 & 7,7 & 9,8 \\
\hline Rosja & 12,5 & 12,9 & 15,3 & 20,7 & 19,3 & 22,2 & $-8,2$ & $-6,4$ & $-6,8$ \\
\hline Singapur & 8,9 & 8,6 & 8,5 & 10,1 & 9,9 & 10,0 & $-1,2$ & $-1,3$ & $-1,5$ \\
\hline USA & 98,5 & 97,3 & 98,2 & 114,8 & 117,3 & 121,8 & $-16,3$ & $-20,1$ & $-23,5$ \\
\hline
\end{tabular}

Źródło: opracowanie własne na podstawie danych Eurostat [ext_it_introle] - dostęp: 12.11.2018. 
Rozwiązanie obserwowanych problemów utrudnia nierównomierny rozkład niedożywienia występujący $\mathrm{w}$ poszczególnych państwach Wspólnoty. Istniejące zróżnicowanie opisują m.in. wyniki badań na temat niedożywienia w Europie i Azji Środkowej przeprowadzone przez S. Capacci i in. (2013, s.7-8). Na wyniki zespołu S. Capacci powołuje się także A.Obiedzińska zestawiając państwa UE w układzie tabelarycznym w czterech grupach ze względu na poziom występującego na ich terenie niedożywienia (tab.4). Autorka zwraca uwage, że „Polska została zaklasyfikowana jako państwo, gdzie niedożywienie ilościowe i jakościowe utrzymuje się na równi bądź poniżej średniej dla tego regionu, podczas gdy nadkonsumpcja jest relatywnie wyższa od innych państw Europy i Azji Środkowej” (Obiedzińska, 2016, s.126).

Tabela 4. Podział państw Unii Europejskiej ze względu na występujące niedożywienie

Table 4. The division of the European Union countries concerning the occurrence of malnutrition

\begin{tabular}{|c|c|c|}
\hline Grupa niedożywienia & Charakterystyka grupy & Państwa Unii Europejskiej \\
\hline Niedożywienie & $\begin{array}{l}\text { Państwa, w których poziom niedożywienia } \\
\text { ilościowego i jakościowego utrzymuje się na } \\
\text { wysokim poziomie, a poziom nadkonsumpcji jest } \\
\text { niski }\end{array}$ & - \\
\hline $\begin{array}{l}\text { Potrójne obciążenie z } \\
\text { powodu } \\
\text { niedożywienia }\end{array}$ & $\begin{array}{l}\text { Państwa, w których niedożywienie ilościowe i } \\
\text { jakościowe utrzymuje się na względnie wysokim } \\
\text { poziomie i występuje relatywnie wyższy poziom } \\
\text { nadkonsumpcji }\end{array}$ & $\begin{array}{l}\text { Bułgaria, Chorwacja, } \\
\text { Cypr, Rumunia }\end{array}$ \\
\hline $\begin{array}{l}\text { Nadmierne } \\
\text { odżywienie } \\
\text { (nadkonsumpcja) }\end{array}$ & $\begin{array}{l}\text { Państwa, w których niedożywienie ilościowe i } \\
\text { jakościowe utrzymuje się na równi bądź poniżej } \\
\text { średniej dla regionu Europy i Azji Środkowej, } \\
\text { podczas gdy nadkonsumpcja jest relatywnie wyższa } \\
\text { niż w innych państwach należących do tego } \\
\text { regionu }\end{array}$ & $\begin{array}{l}\text { Czechy, Niemcy, Węry, } \\
\text { Irlandia, Łotwa, Luksemburg, } \\
\text { Malta, Polska, } \\
\text { Portugalia, Słowacja, } \\
\text { Słowenia, Hiszpania, } \\
\text { Wielka Brytania }\end{array}$ \\
\hline $\begin{array}{l}\text { Problem } \\
\text { niedożywienia nie jest } \\
\text { tak wyraźny }\end{array}$ & $\begin{array}{l}\text { Państwa, w których wszystkie poziomy } \\
\text { niedożywienia bądź nadkonsumpcji są znacznie } \\
\text { poniżej średniej dla państw regionu Europy i } \\
\text { Środkowej Azji }\end{array}$ & $\begin{array}{l}\text { Austria, Belgia, Dania, } \\
\text { Estonia, Finlandia, } \\
\text { Francja, Grecja, Włochy, } \\
\text { Holandia, Szwecja }\end{array}$ \\
\hline
\end{tabular}

Źródło: Capacci i in. (2013, 7-8); Obiedzińska (2016, 126).

Polska i pozostałe państwa Wspólnoty, działając na polu bezpieczeństwa żywnościowego, indywidualnie napotykałyby na znacznie większe trudności w jego zapewnieniu, niż to jest $\mathrm{w}$ sytuacji realizowania wspólnej polityki rolnej (WPR). O postanowieniach zapewnienia ekonomicznej dostępności żywności przeczytać można już w Traktacie rzymskim, w którym znalazł się zapis o konieczności umożliwienia konsumentom nabywania żywności po rozsądnych cenach (Michalczyk, 2013). By tak się stało wszystkim obywatelom UE musi zostać zapewniona odpowiedniej wielkości siła nabywcza, pozwalająca na realizację ich potrzeb żywieniowych.

Postawą i główną składową siły nabywczej jest dochód rozporządzalny gospodarstw domowych. Zgodnie z nomenklaturą GUS stanowi on ,sumę bieżących dochodów gospodarstw domowych z poszczególnych źródeł, pomniejszoną o zaliczki na podatek dochodowy od osób fizycznych płacone przez płatnika w imieniu podatnika, o podatki od dochodów z własności, podatki płacone przez osoby pracujące na własny rachunek, w tym przedstawicieli wolnych zawodów i osób użytkujących gospodarstwo indywidualne 
w rolnictwie oraz o składki na ubezpieczenie społeczne i zdrowotne" (GUS, 2018). Przeciętny roczny dochód rozporządzalny w gospodarstwach domowych w UE wynosił w 2016 roku 18873 EUR (tab. 5). Dochody powyżej średniej unijnej zaobserwować można w 11 państwach Wspólnoty, z czego najwyższe osiagały gospodarstwa domowe w Luksemburgu. Dochody te były ponad 14-krotnie wyższe od najniższych dochodów osiaganych przez rumuńskie gospodarstwa domowe. Wyraźnie mniejsze różnice w wysokości dochodu rozporządzalnego występuja, kiedy jego wartość uwzględnia różne poziomy cen w państwach członkowskich. Wyrażając dochody w jednostkach parytetu siły nabywczej (PPS) można zauważyć obniżenie się siły nabywczej obywateli państw osiagających dochody powyżej średniej unijnej i jej zwiększenie wśród państw w których mieszkańcy osiagają dochody poniżej średniej. W rezultacie przeciętne gospodarstwo domowe w Luksemburgu dysponowało nie 14-krotnie, a 6-krotnie wyższym dochodem od przeciętnego gospodarstwa domowego w Rumunii.

Gospodarstwa domowe państw o wysokich dochodach, charakteryzowały się również wysokimi wydatkami na żywność. Tu również na pierwszym miejscu wymienić należy Luksemburg. W 2016 roku, każdy mieszkaniec tego kraju wydał na żywność 2553 EUR. Zaraz za mieszkańcami Luksemburga wskazać należy Duńczyków, Belgów, Włochów, Szwedów i Finów, których roczne wydatki na żywność per capita przekraczają 2200 EUR. Polacy na artykuły żywnościowe wydawali więcej jedynie od Bułgarów i Węgrów. Analizując poziom wydatków na żywność państw Wspólnoty, różnica pomiędzy wydającym najwięcej Luksemburgiem, a wydającą najmniej Bułgarią była blisko 3,5krotna, a między Luksemburgiem a Polską - niewiele ponad 2,5-krotna. Różnice te nie są więc aż tak wielkie, jak w przypadku opisanej rozpiętości dochodów, a w sytuacji zastosowania PPS, stają się jeszcze niższe. Wynika to rzecz jasna z konieczności nabywania artykułów żywnościowych celem zaspokajania podstawowych potrzeb głodu i pragnienia, ale także z niższego poziomu cen tych dóbr w państwach słabiej rozwiniętych.

Wydatki na żywność stanowią ważną pozycję w budżetach gospodarstw domowych państw UE (tab.5). W 2016 r. w takich krajach jak Bułgaria, Litwa i Rumunia stanowily wciąż największą grupe wydatków konsumpcyjnych, w przypadku Rumunii i Litwy przekraczając nawet $20 \%$ udziału w wydatkach ogółem. W większości państw Unii wysokość wydatków na żywność ustępuje jedynie wydatkom na użytkowanie mieszkania i nośniki energii. Tylko $\mathrm{w}$ niewielu państwach wydatki na żywność spadają na dalsze pozycje, obciążając budżety gospodarstw domowych w mniejszym stopniu, niż wydatki na transport, rekreację i kulturę czy restauracje i hotele. Sytuacja taka ma miejsce jedynie w państwach wysoko rozwiniętych gospodarczo, takich jak: Wielka Brytania czy Austria (Eurostat, 2018a).

Wysoki udział wydatków na artykuły żywnościowe w sposób bezpośredni wpływa na możliwości zaspokojenia innych potrzeb, zwłaszcza wyższego rzędu. Analizując prace innych badaczy, zgodzić należy się z J. Krzysztofiak i K. Pawlak, że niewielkie dochody rozporządzalne gwarantują zaspokojenie głownie potrzeb elementarnych, niezbędnych do przeżycia (2017, s.188). W opublikowanych przez Eurostat w listopadzie 2018 roku wynikach badań EU-SILC z 2017 roku, wciąż ponad połowa mieszkańców UE z większymi bądź mniejszymi trudnościami wiązała koniec z końcem. Oznacza to, że u $51,6 \%$ obywateli państw Unii uzyskiwane dochody rozporządzalne nie wystarczały na pokrycie najważniejszych wydatków. Odsetek gospodarstw odczuwających tego typu trudności w ostatnich latach maleje, co należy uznać za zjawisko pozytywne. W 2015 roku wynosił on 53,8\%, a w 2010 roku - 55,6\% (Eurostat, 2018b). 
Tabela 5. Przeciętny dochód rozporządzalny, wydatki na żywność per capita oraz udział tych wydatków w wydatkach ogółem w państwach UE w 2016 roku

Table 5. Mean equivalised net income by households, food expenditure per capita and food expenditure as a percentage of total households final consumption expenditure in EU in 2016

\begin{tabular}{|c|c|c|c|c|c|}
\hline \multirow[t]{2}{*}{ Państwa } & \multicolumn{2}{|c|}{$\begin{array}{l}\text { Przeciętny dochód } \\
\text { rozporządzalny gospodarstwa } \\
\text { domowego }\end{array}$} & \multicolumn{2}{|c|}{$\begin{array}{l}\text { Wydatki na żywność } \\
\text { per capita }\end{array}$} & \multirow{2}{*}{$\begin{array}{c}\text { Udział wydatków } \\
\text { na żywność } \\
\text { w wydatkach ogółem } \\
\text { w \% }\end{array}$} \\
\hline & w PPS & w Euro & w PPS & w Euro & \\
\hline UE28 & - & 18873 & 1800 & 1762 & 11,1 \\
\hline Austria & 25414 & 26054 & 1500 & 1828 & 8,6 \\
\hline Belgia & 23172 & 24240 & 2000 & 2246 & 12,3 \\
\hline Bułgaria & 8253 & 3855 & 1100 & 779 & 17,9 \\
\hline Chorwacja & 9941 & 6337 & 1300 & 1207 & - \\
\hline Cypr & 19551 & 16943 & 2000 & 2158 & 12,9 \\
\hline Czechy & 14021 & 8808 & 1500 & 1158 & 14,4 \\
\hline Dania & 23919 & 32139 & 1500 & 2247 & 10,1 \\
\hline Estonia & 13877 & 10106 & 1800 & 1589 & 18,7 \\
\hline Finlandia & 22302 & 26379 & 1900 & 2225 & 10,9 \\
\hline Francja & 24009 & 25276 & 1900 & 2146 & 12,3 \\
\hline Grecja & 10491 & 8682 & 1900 & 1936 & 16,3 \\
\hline Hiszpania & 17755 & 15842 & 1700 & 1676 & 11,7 \\
\hline Holandia & 23663 & 25381 & 1900 & 1907 & 10,7 \\
\hline Irlandia & 20870 & 25513 & 1300 & 1532 & 8,6 \\
\hline Litwa & 11646 & 7023 & 2300 & 1785 & 20,6 \\
\hline Luksemburg & 32604 & 39416 & 2100 & 2553 & 8,2 \\
\hline Lotwa & 10930 & 7534 & 1400 & 1281 & 16,5 \\
\hline Malta & 19513 & 15393 & 1200 & 1324 & 10,5 \\
\hline Niemcy & 23910 & 24020 & 1700 & 1793 & 9,4 \\
\hline Polska & 12315 & 6676 & 1600 & 996 & 15,4 \\
\hline Portugalia & 12987 & 10562 & 2000 & 1945 & 15,9 \\
\hline Rumunia & 5305 & 2747 & 2300 & 1394 & 26,4 \\
\hline Słowacja & 11132 & 7391 & 1500 & 1302 & 16,2 \\
\hline Słowenia & 16320 & 13193 & 1500 & 1489 & 13,5 \\
\hline Szwecja & 22567 & 27364 & 1700 & 2226 & 11,0 \\
\hline Węgry & 9363 & 5397 & 1100 & 898 & 15,2 \\
\hline Wielka Brytania & 20218 & 24603 & 1700 & 1617 & 7,1 \\
\hline Włochy & 18248 & 18286 & 2000 & 2235 & 13,1 \\
\hline
\end{tabular}

Źródło: opracowanie własne na podstawie danych Eurostat [ilc_di04], [prc ppp ind], [nama 10 co p3] - dostęp: 17.08.2018.

Problem wiązania końca $\mathrm{z}$ końcem przybiera różne rozmiary $\mathrm{w}$ poszczególnych państwach Wspólnoty. Największy odsetek gospodarstw domowych, deklarujących trudności w pokryciu wydatków osiagganymi dochodami, zaobserwowano w Grecji (94,3\% gospodarstw deklarujących większe lub mniejsze trudności), Bułgarii (89,0\%), Chorwacji $(85,1 \%)$ i Rumunii $(81,0 \%)$. Ponad $3 / 4$ gospodarstw domowych zgłaszało trudności na 
Litwie, Łotwie i na Węgrzech oraz - co jest pewnym zaskoczeniem - we Włoszech. Najkorzystniej swoją sytuację dochodową oceniły gospodarstwa domowe w Niemczech i Szwecji. W państwach tych z trudnościami w pokryciu wydatków boryka się odpowiednio 15,6\% i 17,2\% gospodarstw domowych. Polska wśród krajów Wspólnoty plasuje się na 13 miejscu, tuż za Czechami, i pozycję przed Francją. W 2017 roku trudności z pokryciem wydatków uzyskiwanymi dochodami deklarowało $57,4 \%$ polskich gospodarstw domowych (tab. 6).

Różnice w ekonomicznej dostępności żywności gospodarstw domowych widoczne są także w podziale na żywność nisko i wysokoprzetworzoną. W tabeli 7 zaprezentowano obliczenia ukazujące, ile danego artykułu żywnościowego mogą nabyć gospodarstwa domowe za swój roczny dochód. Oprócz informacji na temat wysokości dochodów do analizy wykorzystano statystyki na temat średnich cen poszczególnych artykułów żywnościowych $\mathrm{z}$ państw udostępniających tego typu dane. Jak już to zostało przedstawione wcześniej, państwa wysoko rozwinięte, o wysokich dochodach mieszkańców dysponują większą ekonomiczną dostępnością żywności od państw, w których obywatele są niżej uposażeni. Różnice te zwiększają się jeszcze bardziej w przypadku ekonomicznego dostępu do żywności wysokoprzetworzonej. I tak na przykład, Holendrzy, którzy w tym zestawieniu dysponowali największymi dochodami, mogliby za nie kupić 25727 litrów świeżego mleka, podczas gdy obywatele Rumunii, dysponujący dochodami najniższymi - 2624 , czyli blisko 10-krotnie mniej. Ale już w przypadku masła Holendrzy mogliby nabyć 18692 kostki - Rumuni 1 345, czyli blisko 14-krotnie mniej. Jeszcze wyraźniejsze różnice zaobserwować można na przykładzie ziemniaków i frytek mrożonych. Przeciętne holenderskie gospodarstwo domowe za swój dochód może kupić blisko 3-kronie więcej ziemniaków, niż przeciętne gospodarstwo domowe z Rumunii - ale już ponad 10-krotnie więcej mrożonych frytek.

Zapewnienie ekonomicznej dostępności żywności wszystkim obywatelom państw UE pozostaje wciąż aktualnym, ważnym i wielopłaszczyznowym problemem. Potwierdzają to także wyniki badań innych autorów, przywoływanych choćby w tej pracy. J. Krzysztofiak i K. Pawlak wskazały m.in., że w latach 2010-2015 poprawa lub pogorszenie dostępności ekonomicznej żywności była bardzo silnie uwarunkowana szybkością wzrostu dochodów rozporządzalnych $\mathrm{w}$ stosunku do wzrostów cen towarów i usług konsumpcyjnych. Badaczki polepszenie dostępności ekonomicznej żywności na skutek szybszego wzrostu dochodów niż cen zaobserwowały w Szwecji, Danii, Belgii, Wielkiej Brytanii, Francji, na Malcie, Słowacji, w Estonii, na Litwie, w Polsce, na Łotwie, w Rumunii i Bułgarii. Z kolei pogorszenie poziomu dostępności ekonomicznej żywności zaobserwowały szczególnie w państwach, w których dochód rozporządzalny zmniejszył się, czyli we Włoszech, w Hiszpanii, Portugalii, Grecji, Chorwacji i na Cyprze. (Krzysztofiak i Pawlak, 2017). Podziały na „starych" i „nowych” członków UE, choć wciąż widoczne choćby w poziomie PKB per capita, stają się zatem coraz mniej wyraźne, szczególnie gdy patrzy się na nie przez pryzmat dochodów wyrażanych w jednostkach parytetu siły nabywczej. 
Tabela 6. Rozkład pokrycia miesięcznych wydatków dochodami w 2017 roku na podstawie subiektywnych opinii gospodarstw domowych państw UE (w \%)

Table 6. Distribution of coverage of monthly expenditure by income in 2017 based on subjective opinions of EU countries` households (in\%)

\begin{tabular}{|c|c|c|c|c|c|c|}
\hline \multirow[b]{2}{*}{ Państwa } & \multicolumn{6}{|c|}{ Gospodarstwa domowe wiążące koniec z końcem } \\
\hline & $\begin{array}{l}\text { z dużym } \\
\text { trudem }\end{array}$ & $\mathrm{z}$ trudem & $\begin{array}{l}\text { z pewnym } \\
\text { trudem }\end{array}$ & dość łatwo & łatwo & bardzo łatwo \\
\hline UE28 & 7,8 & 14,2 & 29,6 & 27,9 & 15,4 & 5,0 \\
\hline Austria & 4,5 & 7,0 & 24,0 & 31,0 & 22,6 & 10,7 \\
\hline Belgia & 8,5 & 12,4 & 16,4 & 26,5 & 28,8 & 7,4 \\
\hline Bułgaria & 28,0 & 30,4 & 30,6 & 8,7 & 1,9 & 0,4 \\
\hline Chorwacja & 15,5 & 28,4 & 41,2 & 11,5 & 2,8 & 0,5 \\
\hline Cypr & 22,2 & 21,4 & 30,2 & 17,4 & 7,4 & 1,3 \\
\hline Czechy & 7,4 & 14,6 & 34,9 & 31,9 & 9,3 & 1,9 \\
\hline Dania & 3,4 & 6,0 & 16,2 & 29,7 & 28,6 & 16,0 \\
\hline Estonia & 3,7 & 10,6 & 41,2 & 32,2 & 10,6 & 1,7 \\
\hline Finlandia & 2,3 & 4,4 & 18,2 & 38,1 & 23,6 & 13,4 \\
\hline Francja & 4,1 & 14,0 & 39,7 & 28,2 & 12,2 & 1,8 \\
\hline Grecja & 39,9 & 37,3 & 17,1 & 4,2 & 1,2 & 0,2 \\
\hline Hiszpania & 9,5 & 15,6 & 28,1 & 32,5 & 13,3 & 0,9 \\
\hline Holandia & 3,2 & 8,3 & 15,2 & 21,9 & 37,8 & 13,7 \\
\hline Irlandia $^{a}$ & 12,0 & 15,4 & 36,7 & 25,4 & 7,7 & 2,7 \\
\hline Litwa & 7,1 & 21,1 & 50,8 & 17,2 & 3,2 & 0,6 \\
\hline Luksemburg & 5,1 & 7,5 & 17,6 & 35,9 & 25,8 & 8,1 \\
\hline Łotwa & 13,5 & 27,0 & 36,9 & 17,3 & 4,7 & 0,6 \\
\hline Malta & 4,6 & 11,1 & 27,2 & 38,9 & 16,1 & 2,1 \\
\hline Niemcy & 2,1 & 4,0 & 9,5 & 39,4 & 32,2 & 12,8 \\
\hline Polska & 6,8 & 15,3 & 35,3 & 30,2 & 9,5 & 2,8 \\
\hline Portugalia & 15,2 & 18,4 & 37,0 & 21,5 & 7,1 & 0,8 \\
\hline Rumunia & 14,7 & 22,7 & 43,6 & 14,1 & 4,0 & 0,9 \\
\hline Słowacja & 8,1 & 18,1 & 40,7 & 26,6 & 5,7 & 0,7 \\
\hline Słowenia & 6,5 & 16,1 & 36,5 & 25,7 & 13,8 & 1,3 \\
\hline Szwecja & 2,9 & 4,1 & 10,2 & 32,8 & 27,4 & 22,6 \\
\hline Węgry & 15,7 & 25,5 & 37,2 & 18,8 & 2,5 & 0,3 \\
\hline Wielka Brytania & 5,4 & 7,1 & 24,9 & 35,5 & 17,0 & 10,1 \\
\hline Włochy & 8,6 & 19,5 & 47,5 & 21,4 & 2,9 & 0,2 \\
\hline
\end{tabular}

a - dane dla Irlandii z 2016 roku.

Źródło: opracowanie własne na podstawie danych Eurostat [ilc_mdes09] - dostęp: 12.11.2018. 
Tabela 7. Przeciętny ekwiwalentny dochód rozporządzalny gospodarstw domowych w wybranych państwach europejskich wyrażony wielkością niektórych artykułów żywnościowych w 2015 roku

Table 7. Mean equivalised net income by households in selected countries of Europe expressed by the value of certain foods in 2015

\begin{tabular}{|c|c|c|c|c|c|c|c|c|c|c|c|c|}
\hline \multirow{2}{*}{ Państw } & MP & $\mathrm{ChB}$ & M1 & $\mathrm{Ma}$ & $\mathrm{Ku}$ & WM & Po & $\mathrm{Zi}$ & $\mathrm{KP}$ & FM & $\mathrm{KS}$ & $\mathrm{SG}$ \\
\hline & $1 \mathrm{~kg}$ & $1 \mathrm{~kg}$ & 11 & $250 \mathrm{~g}$ & $1 \mathrm{~kg}$ & $1 \mathrm{~kg}$ & $1 \mathrm{~kg}$ & $1 \mathrm{~kg}$ & $1 \mathrm{~kg}$ & $1 \mathrm{~kg}$ & $1 \mathrm{~kg}$ & $1 \mathrm{~kg}$ \\
\hline Bułgaria & 7442 & 5932 & 3861 & 1878 & 1631 & - & 3936 & 8898 & 2607 & 2862 & 484 & 378 \\
\hline Chorwacja & 8093 & 3818 & 7494 & 2836 & 1984 & 848 & 3229 & 9790 & 2628 & 3592 & 536 & 753 \\
\hline Cypr & 14239 & 8186 & 12836 & 6517 & 4447 & 2265 & 12836 & 23865 & 5448 & 7272 & 2480 & 1517 \\
\hline Czechy & 18141 & 10177 & 10838 & 5877 & 3285 & 2225 & 5282 & 17031 & 3918 & 6785 & 1175 & 1264 \\
\hline Finlandia & 39170 & 6834 & - & 21165 & - & 2581 & 11984 & 29822 & 7788 & 11215 & 1651 & - \\
\hline Hiszpania & 20010 & 5523 & 19754 & - & 5331 & - & - & 18790 & - & - & - & - \\
\hline Holandia & 45143 & 15048 & 25727 & 18692 & 4923 & 4055 & 11286 & 21950 & 8545 & 18126 & 1562 & 3478 \\
\hline Litwa & 9513 & 4103 & 8005 & 3931 & 2781 & 1523 & 4405 & 18233 & 3011 & 4154 & 687 & 964 \\
\hline Malta & 16310 & 7257 & 18274 & 5576 & 4909 & 2170 & 8025 & 23700 & 4815 & 5856 & 910 & 1288 \\
\hline Niemcy & - & - & - & 19563 & 9135 & 3151 & - & - & - & - & 1291 & 4585 \\
\hline Polska & 11416 & 6089 & 10148 & 5198 & 3828 & 2030 & 4471 & 24588 & 2557 & 3073 & 823 & 1405 \\
\hline Rumunia & 4316 & 2731 & 2624 & 1345 & 1179 & 648 & 2230 & 7645 & 1163 & 1761 & - & 347 \\
\hline Słowacja & 15854 & - & 7927 & 3628 & 2929 & - & 3879 & 14300 & 2964 & 4767 & 988 & 935 \\
\hline Słowenia & 17852 & 7958 & 15013 & 6845 & 3690 & 1879 & 6810 & 24465 & 5482 & 9174 & 1070 & 1565 \\
\hline Włochy & 24176 & 6148 & 12510 & 8169 & 3727 & 1725 & 6106 & 17202 & - & 7454 & 988 & 1737 \\
\hline Norwegia & 27823 & 20421 & 23806 & 15842 & 7935 & 4032 & 12366 & 19188 & 11593 & 25882 & 1573 & 3527 \\
\hline Turcja & 5063 & 4122 & 5009 & 1738 & 2218 & 485 & 6211 & 6850 & 2089 & - & - & - \\
\hline
\end{tabular}

Legenda: MP - mąka pszenna, ChB - chleb biały, bochenek, WM - wołowina mielona, Ku- kurczak cały, Ml mleko świeże, Ma - masło niesolone, Po - pomidory świeże, Zi - ziemniaki, KP - keczup pomidorowy, FM frytki mrożone, KS - kiełbasa salami, $\mathrm{SG}$ - ser gouda.

Źródło: opracowanie i obliczenia własne na podstawie danych Eurostat [ilc_di04], [prc_dap15] - dostęp: 17.08.2018.

Z kolei zdaniem A. Dąbrowskiej i I. Ozimek ekonomiczną dostępność żywności można poprawić niezależnie od wysokości uzyskiwanych dochodów czy posiadanej siły nabywczej. Kluczem jest ograniczenie zbędnej konsumpcji (nadkonsumpcji) i bardziej racjonalne zachowania konsumentów w zakresie nabywania i niemarnowania żywności (Dąbrowska i Ozimek, 2014).

Natomiast A. Obiedzińska w swych badaniach dowodzi, że zapewnienie żywności zarówno dla obecnej populacji, jak i stworzenia odpowiednich warunków dla przyszłych pokoleń zależy przede wszystkim od wydajności łańcucha rolno-żywnościowego. Poprawa jego wydajności powinna być zadaniem każdego z państw członkowskich. Najpewniej osiagnąc ją można poprzez ograniczanie oraz prewencję strat i marnotrawstwa żywności (Obiedzińska, 2017). 


\section{Podsumowanie}

Państwa Unii Europejskiej stanowią obecnie drugą siłę gospodarczą na świecie. Wysoki rozwój gospodarczy oraz osiągane wartości PKB nie oznaczają jednak, że wśród obywateli Wspólnoty przestał istnieć problem niedożywienia i niewłaściwego odżywiania. Przeprowadzone na potrzeby niniejszego artykułu badania oraz badania innych autorów powoływane w prezentowanym tekście, dowodzą występowania problemu ekonomicznej dostępności żywności w państwach Unii Europejskiej i konieczności jej poprawy. Problem szczególnie dotyczy nowych państw członkowskich z Europy Środkowo-Wschodniej oraz państw gorzej radzących sobie ze skutkami niedawnego kryzysu finansowego. Dlatego też kwestią kluczową Państw Wspólnoty w dalszym ciąu pozostaje zagwarantowanie każdemu obywatelowi Unii siły nabywczej umożliwiającej mu pozyskanie odpowiedniej ilości żywności fizycznie dostępnej, wolnej od zanieczyszczeń i optymalnej pod względem składników odżywczych. Koniecznym zatem staje się prowadzenie dalszych, systematycznych badań w zakresie monitorowania sytuacji materialnej obywateli Wspólnoty. Celem takich badań powinna być identyfikacja obszarów ubóstwa i nierówności społecznych, aby móc skutecznie i optymalnie redukować te obszary poprzez stosowanie różnych instrumentów finansowych takich jak, dokonywanie transferów socjalnych redukujących ubóstwo i nierówności dochodowe czy ustalanie płac minimalnych na poziomie zapewniającym bezpieczeństwo ekonomiczne obywateli.

\section{Literatura}

Arora, V.S., Karanikolos, M., Clair, A., Reeves, A., Stuckler, D., McKee, M. (2015). Data Resource Profile: The European Union Statistics on Income and Living Conditions (EU-SILC). International Journal of Epidemiology, 44(2), 451-461. DOI: 10.1093/ije/dyv069.

Capacci, S., Mazzocchi, M., Shankar, B., Traill, B. (2013). The triple burden of malnutrition in Europe and Central Asia: a multivariate analysis. FAO Regional Office for Europe and Central Asia Policy Studies on Rural Transition 7, 7-8.

CFS (2012), Coming to Terms with Terminology. Committee on World Food Security, Rome.

Copeland, P., Daly, M. (2012). Varieties of poverty reduction: Inserting the poverty and social exclusion target into Europe 2020. Journal of European Social Policy, 22/3, 273-287. DOI: 10.1177/0958928712440203.

Dąbrowska, A., Ozimek, I. (2014). Bezpieczeństwo żywnościowe konsumentów w Polsce - wybrane aspekty (Food Security of Consumers in Poland - the Selected Aspects). Handel Wewnetrzny, 4(351), 55-69.

European Commission (2009). Food security: understanding and meeting the challenge of poverty. Publications Office of the European Union, Luxembourg. DOI: 10.2783/28748.

EUROSTAT (2018a). Final consumption expenditure of households by consumption purpose. Pobrane 17 sierpnia $2018 \mathrm{z}$ http://appsso.eurostat.ec.europa.eu/nui/submitViewTableAction.do

EUROSTAT (2018b). Inability to make ends meet - EU-SILC survey. Pobrane 12 listopada 2018 z http://appsso.eurostat.ec.europa.eu/nui/submitViewTableAction.do

FAO, IFAD, UNICEF, WFP and WHO (2018). The State of Food Security and Nutrition in the World 2018. Building climate resilience for food security and nutrition. FAO, Rome.

Gawęcki, J. (2004). Relacje między żywnością, żywieniem a zdrowiem (Relations Between Food, Nutrition and Health). W: J. Gawęcki, T. Mossor-Pietraszewska (red.), Kompendium wiedzy o żywności, żywieniu i zdrowiu (Compendium of Knowledge about Food, Nutrition and Health). Wydawnictwo Naukowe PWN, Warszawa.

GUS (2013). Systemy ważenia w badaniach cen towarów i usług konsumpcyjnych (Weighing systems in price surveys consumer goods and services). Pobrane 12 listopada 2018 z http://stat.gov.pl/gfx/portalinformacyjny/userfiles/ public/wyniki wstepne/coicop 12 2013.pdf

GUS (2017). Rachunki narodowe według sektorów i podsektorów instytucjonalnych $\bar{w}$ latach 2012-2015 (National Accounts by Institutional Sectors and Sub-Sectors 2012-2015). GUS, Warszawa. 
GUS (2018). Pojęcia stosowane w statystyce publicznej. Pobrane $20 \quad$ sierpnia $2018 \quad \mathrm{z}$ https://stat.gov.pl/metainformacje/slownik-pojec/pojecia-stosowane-w-statystyce-publicznej/63,pojecie.html Kowalczyk, S. (2009). Bezpieczeństwo żywności w erze globalizacji (Food security in the era of globalization). Oficyna Wydawnicza SGH, Warszawa.

Kapusta, F. (2016). Bezpieczeństwo żywnościowe Polski i jej mieszkańców w okresie przedakcesyjnym i po akcesji do Unii Europejskiej (Food Security of Poland and Its Inhabitants During the Pre-Accession and After Accession Period to the European Union). Ekonomia XXI Wieku, 4, 68-90. DOI: 10.15611/e21.2016.4.06.

Kramer, J. (2011). Konsumpcja - ewolucja ról i znaczeń (Consumption - the evolution of roles and meanings). Konsumpcja i Rozwój, 1, 5-15.

Krzysztofiak, J., Pawlak, K. (2017). Ekonomiczna dostępność żywności w gospodarstwach domowych krajów Unii Europejskiej (Economic access to food in European Union households). Zeszyty Naukowe Polskiego Towarzystwa Ekonomicznego w Zielonej Górze, 7, 179-195.

Małysz, J. (2008). Bezpieczeństwo żywnościowe strategiczną potrzebą ludzkości (Food Security is a Strategic Need of Humanity). Wydawnictwo Druk Tur, Warszawa.

Marzęda-Młynarska, K. (2014), Globalne zarządzanie bezpieczeństwem żywnościowym na przełomie XX i XXI wieku (Global food security management at the turn of the 20th and 21st centuries). Wydawnictwo Uniwersytetu Marii Curie-Skłodowskiej, Lublin.

Maslow, A.H. (2018). Motywacja a osobowość (Motivation and Personality). Wydawnictwo Naukowe PWN, Warszawa.

Michalczyk, J. (2012). Bezpieczeństwo żywnościowe w obliczu globalizacji (Food Security in The Face of Globalization). Ekonomia, 1(18), 9-23.

Michalczyk, J. (2013), Główne przesłanki bezpieczeństwa żywnościowego polski i próba jego pomiaru (Main Determinants of Poland's Food Security and an Attempt of its Measuring). Prace Naukowe Uniwersytetu Ekonomicznego we Wroctawiu, 315 (1), 577-591.

Obiedzińska, A. (2016). Wybrane aspekty zapewnienia bezpieczeństwa żywnościowego w Unii Europejskiej (Selected Aspects of Food Security in the European Union). Studia BAS, 4(48), 123-161.

Obiedzińska, A. (2017). Wpływ strat i marnotrawstwa żywności na bezpieczeństwo żywnościowe (Impact of Food Losses and Waste on Food Security). Zeszyty Naukowe SGGW w Warszawie Problemy Rolnictwa Światowego, 17(1), 125-141. DOI: 10.22630/PRS.2017.17.1.12.

ONZ (2018). Zrównoważony rozwój i Cele Zrównoważonego Rozwoju (Sustainable Development and Sustainable Development Goals) Pobrane 10 listopada $2018 \mathrm{z}$ http://www.unic.un.org.pl/strony-20112015/zrownowazony-rozwoj-i-cele-zrownowazonego-rozwoju/2860\#

Shaw, J. (2007). World Food Security. A History since 1945. Basingstoke-New York.

WHO (2016). What is malnutrition? Pobrane 16 sierpnia $2018 \mathrm{z} \mathrm{http://www.who.int/features/qa/malnutrition/en/.}$

Do cytowania / For citation:

Maciejewski G. (2018). Ekonomiczna dostępność żywności w państwach Unii Europejskiej. Problemy Rolnictwa Światowego, 18(4), 345-358; DOI: 10.22630/PRS.2018.18.4.124

Maciejewski G. (2018). Economic Access to Food in Countries of the European Union (in Polish). Problems of World Agriculture, 18(4), 345-358; DOI: 10.22630/PRS.2018.18.4.124 